\title{
PENERAPAN PROJECT BASED LEARNING BERBASIS GRASPS UNTUK MENINGKATKAN HASIL BELAJAR SISWA PADA MATA DIKLAT MPMB KELAS XI SMK SEMEN PADANG TAHUN AJARAN 2016/2017
}

\author{
APPLICATION PROJECT BASED LEARNING BASED GRASPS \\ TO IMPROVE STUDENT LEARNING OUTCOMES IN MPMB \\ LESSONS CLASS XI SMK SEMEN PADANG ACADEMIC \\ YEARS 2016/2017
}

\author{
Daniel Fifaldi Nardo ${ }^{(1)}$, Nizwardi Jalinus. ${ }^{2)}$, Arwizet K, ${ }^{(3)}$ \\ (1),(2),(3) Jurusan Teknik Mesin, Fakultas Teknik, Universitas Negeri Padang \\ Kampus Air Tawar, Padang 25131, Indonesia \\ adm.dafido@gmail.com \\ nizwardijalinus@gmail.com \\ arwizet@yahoo.com
}

\begin{abstract}
Abstrak
Tujuan dilaksanakannya penelitian ini adalah untuk mengetahui peningkatan hasil belajar siswa pada mata diklat Melakukan Pekerjaan dengan Mesin Bubut setelah mengikuti pembelajaran dengan metode pembelajaran berbasis proyek (project based learning).

Penelitian ini dilaksanakan dengan rancangan penelitian tindakan kelas dengan 3 siklus. Subjek dalam penelitian ini adalah siswa kelas XI TM1 SMK Semen Padang tahun ajaran 2016/2017 yang berjumlah 31 siswa. Pengumpulan data dilakukan dengan menggunakan instrumen penilaian otentik pelaksanaan (project based learning) berupa hasil sikap dan keterampilan. Analisis data penelitian dilakukan melalui analisis deskriptif kuantitatif.

Hasil penelitian menunjukkan bahwa ada peningkatan hasil belajar siswa pada mata diklat Melakukan Pekerjaan dengan Mesin Bubut melalui implementasi pembelajaran berbasis proyek. Pada Siklus I, hasil belajar meningkat dari presentase ketuntasan $52 \%$ menjadi $67,74 \%$ pada penilaian sikap dan $58 \%$ pada penilaian keterampilan. Pada Siklus II, hasil belajar meningkat dari presentase ketuntasan $58 \%$ menjadi $77,42 \%$ pada penilaian keterampilan dan meningkat dari 67,74 menjadi 74,2 \% pada penilaian sikap. Pada Siklus III, hasil belajar meningkat dari presentase ketuntasan $77,42 \%$ menjadi $87,1 \%$ pada penilaian keterampilan dan meningkat dari $74,2 \%$ menjadi $96,77 \%$ pada penilaian sikap. Penerapan metode pembelajaran berbasis proyek (project based learning) dapat meningkatkan hasil belajar siswa pada mata diklat Melakukan Pekerjaan dengan Mesin Bubut.
\end{abstract}

Kata Kunci: Pembelajaran Berbasis Proyek, GRASPS, Hasil Belajar, MPMB, SMK Semen Padang.

\begin{abstract}
The objective of this study was to determine the improvement of student learning outcomes in subjects lathe machining technique in class XI TM1 Department of Mechanical Engineering SMK Semen Padang after following project based learning method. This research was carried out with the design of classroom action research with three cycles. Subjects in this study is a class XI TM1 student of SMK Semen Padang school year $2016 / 2017$ total student is 31. Data collected through authentic assessment instruments in the form of attitude and skill assessment. The data analysis research conducted through descriptive analysis of quantitative.

The results showed that there was an increase in student learning outcomes in the lessons of Doing a job by using Lathe Machining through the implementation of project based learning. In the first cycle, the learning outcomes improved from an average 52\% became 67,74 on attitude assessment and 58\% on the skill assessment. In the second cycle, the learning outcomes again experienced an average improved from 67,74 to 74,2\% on attitude assessment and increase from $58 \%$ to $77,42 \%$ on the skill assessment. In the third cycle, the learning outcomes again experienced an average improved from 74,2\% to 96,77\% on attitude assessment and increase from $77,42 \%$ to $87,1 \%$ on the skill assessment. The application of project-based learning method can improved student learning outcomes in learning work lathe machining in class XI TM1 SMK Semen Padang".
\end{abstract}

Keywords: Project Based Learning, GRASPS, Learning Outcomes, MPMB, SMK Semen Padang. 


\section{Pendahuluan}

Pendidikan mempunyai peranan penting sebagai ujung tombak dalam menentukan masa depan bangsa, tanpa pendidikan tidak akan ada penerus cita-cita luhur untuk mencapai kesejahteraan dan kemajuan bangsa. Melalui pendidikan yang berkualitas maka masyarakat mempunyai peranan dalam melakukan perubahan dan pembangunan bangsa. Pendidikan berkualitas bisa ditempuh melalui Sekolah Dasar, Sekolah Menengah Pertama, Sekolah Menengah Atas sampai Perguruan Tinggi. Pendidikan berguna untuk mengikuti perkembangan ilmu pengetahuan dan teknologi. Penerapan teknologi hanya bisa dilakukan oleh mereka yang memiliki tingkat pendidikan yang baik dan memadai.

Proses pembelajaran pada satuan pendidikan diselenggarakan secara interaktif, inspiratif, menyenangkan, menantang, memotivasi peserta didik untuk berpartisipasi aktif, serta memberikan ruang yang cukup bagi prakasa, kreativitas, dan kemandirian sesuai bakat, minat dan pengembangan fisik serta psikologis peserta didik. Pendidikan formal pada tingkat menengah yang membekali peserta didiknya dengan keahlian dan keterampilan di bidang tertentu dalam menghadapi dunia kerja di industri adalah Sekolah Menengah Kejuruan (SMK). Menurut undang-undang No. 20 Tahun 2003 Tentang Sistem Pendidikan Nasional, pendidikan kejuruan adalah pendidikan menengah yang mempersiapkan peserta didik terutama untuk bekerja dalam bidang tertentu. SMK mempunyai peran strategis dalam mendukung secara langsung pembangunan nasional, khususnya dalam mempersiapkan tenaga kerja yang terampil dan terdidik yang dibutuhkan oleh dunia industri. SMK Semen Padang yang berlokasi di Komplek PT Semen Padang, merupakan salah satu sekolah menengah kejuruan swasta yang ada di Kota Padang. Sejalan dengan tujuan SMK, maka siswa di SMK Semen Padang dibekali dengan pengetahuan sesuai dengan jurusan masing-masing yang terangkum dalam mata pelajaran tertentu. Salah satu kompetensi yang harus dikuasai di Jurusan Teknik Pemesinan SMK Semen Padang adalah Melakukan Pekerjaan dengan Mesin Bubut (MPMB). Mata pelajaran ini diberikan di kelas XI dengan metode ceramah, demonstrasi dan praktik langsung menggunakan mesin.

Hasil pengamatan yang dilakukan di kelas XI TM1 berdasarkan pengalaman pribadi selama mengikuti kegiatan mengajar dalam kegiatan Praktek Lapangan Kependidikan pada Juli-Desember 2016 dan kolaborasi dengan guru pengampuh mata pelajaran menunjukkan bahwa pencapaian hasil belajar siswa masih kurang optimal. Hal ini dapat dilihat dari presentasi nilai siswa pada tabel berikut :
Tabel 1. Presentase Nilai Semester Siswa Kelas XI TM1 Semester I T.A. 2016/2017 SMK Semen Padang.

\begin{tabular}{|c|c|c|c|}
\hline No. & Nilai & Jumlah Siswa & Presentase \\
\hline 1. & $0-25$ & 0 & $0 \%$ \\
\hline 2. & $25-50$ & 8 & $34,8 \%$ \\
\hline 3 & $51-74$ & 10 & $43,5 \%$ \\
\hline 4. & $75-100$ & 4 & $21,7 \%$ \\
\hline
\end{tabular}

Sumber : Nilai Guru Mata Diklat

Asumsi dasar yang menyebabkan pencapaian hasil belajar siswa kurang optimal adalah prestasi belajar dan kurangnya keaktifan siswa dalam proses pembelajaran. Permasalahan yang ditemukan di antaranya adalah pembelajaran belum mengembangkan kemampuan siswa secara menyeluruh mencakup ranah afektif, kognitif, dan psikomotorik.

Berdasarkan pertimbangan di atas, maka perlu dikembangkan suatu model pembelajaran yang mampu melibatkan peran siswa secara menyeluruh sehingga kegiatan pembelajaran tidak hanya didominasi oleh siswa-siswa tertentu saja. Selain itu, melalui pemilihan model pembelajaran tersebut diharapkan sumber informasi yang diterima siswa tidak hanya dari guru melainkan juga dapat meningkatkan keaktifan siswa dalam mempelajari dan menelaah ilmu yang ada terutama tentang gambar teknik.

Strategi yang dapat diterapkan untuk memecahkan persoalan tersebut salah satunya dengan mengedepankan pembelajaran praktik kejuruan berbasis proyek. Made Wena (2011: 108) strategi pembelajaran berbasis proyek terdiri atas tiga tahap utama, yaitu tahap perencanaan pembelajaran proyek, tahap pelaksanaan pembelajaran proyek, dan tahap evaluasi pembelajaran proyek. Ketiga tahap itu merupakan satu kesatuan yang saling menunjang dan berhubungan, dalam usaha mencapai tujuan pembelajaran proyek secara optimal. Berdasarkan latar belakang masalah, maka dirumuskan judul penelitian:

"Penerapan Project Based Learning Berbasis GRASPS untuk Meningkatkan Hasil Belajar Siswa pada Mata Diklat MPMB Kelas XI SMK Semen Padang Tahun Ajaran 2016/2017”.

\section{Metodologi Penelitian}

\section{A. Desain Penelitian}

Penelitian ini dilaksanakan dengan rancangan penelitian tindakan kelas (classroom action reseach) dengan mengkombinasikan prosedur penelitian dengan tindakan substantif. Penelitian tindakan kelas merupakan suatu bentuk kajian yang bersifat reflektif oleh pelaku tindakan. Penelitian ini dilakukan untuk 
meningkatkan kemampuan rasional dari tindakantindakan dalam melaksanakan tugas, memperdalam pemahaman terhadap tindakan-tindakan yang dilakukan, serta memperbaiki kondisi di mana pembelajaran dilakukan.

Tahap-tahap penelitian tindakan menurut model Kurt Lewin (dalam Kusumah, 2010:20) terdiri empat komponen yaitu perencanaan (planning), tindakan (acting), pengamatan (observing), dan refleksi (reflecting).

\section{B. Tempat dan Waktu Penelitian}

Penelitian ini dilakukan di SMK Semen Padang dan yang menjadi subjek penelitiannya adalah kelas XI. Waktu penelitian dilaksanakan pada bulan Juni-Juli 2017.

\section{Subjek Penelitian}

Penelitian ini dilaksanakan di SMK Semen Padang pada kelas XI TM1 Jurusan Teknik Mesin dengan jumlah 31 orang siswa. Alasannya adalah peneliti memiliki pengalaman mengajar pada kelas tersebut sehingga akan memudahkan komunikasi dalam menjalankan penelitian.

Tabel 2. Jumlah Siswa SMK Semen Padang

\begin{tabular}{|c|c|}
\hline Kelas & Jumlah Siswa \\
\hline XI TM 1 & 31 \\
\hline
\end{tabular}

Sumber : SMK Semen Padang

\section{Prosedur Penelitian}

Penelitian ini dilaksanakan sebanyak tiga siklus. Untuk kelancaran penelitian, diperlukan prosedur dalam penelitian yang berhubungan dengan masalah yang akan diteliti yaitu dalam bentuk persiapan penelitian. Secara keseluruhan rankaian kegiatan dalam siklus ini dapat ditunjukkan pada gambar berikut :

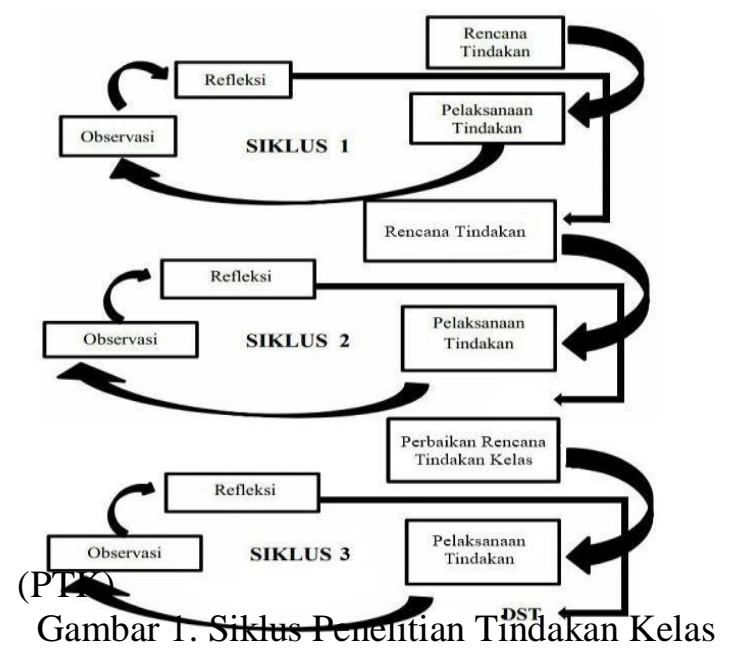

\section{E. Instrumen dan Teknik Pengumpulan Data}

Instrumen yang digunakan dalam penelitian ini adalah penilaian autentik (authentic assesment) adalah suatu proses pengumpulan, pelaporan dan penggunaan informasi tentang hasil belajar siswa dengan menerapkan prinsip-prinsip penilaian, pelaksanaan berkelanjutan, bukti-bukti autentik, akurat, dan konsisten sebagai akuntabilitas publik (Pusat Kurikulum: 2009). Bentuk Penilaian Autentik yang digunakan dalam penelitian ini adalah berupa penilaian sikap dan penialaian proyek.

Teknik Pengumpulan Data Analisis data dilakukan sejak awal sampai akhir kegiatan pengumpulan data pada penelitian ini. Teknik analisis data yang digunakan dalam penelitian ini adalah kuantitatif untuk data yang diperoleh dari hasil penilaian dalam setiap siklus. Pada penelitian ini, data dikumpulkan menggunakan beberapa instrumen pengumpulan data, yaitu penilaian autentik.

\section{a. Pengumpulan Data Penilaian Sikap}

Aspek penilaian aktivitas sikap siswa kelas XITM1 SMK Semen Padang yang akan diamati selama proses pembelajaran dilakukan dengan menggunakan daftar check list ketika melaksanakan pembelajaran berbasis proyek. Setiap aspek yang akan dinilai di beri tanda ceklis pada lembar pengamatan aktivitas siswa yang terdapat pada tabel.

Tabel 3. Instrumen Penilaian Sikap.

\begin{tabular}{|c|l|l|l|l|l|l|}
\hline \multirow{2}{*}{ No } & \multicolumn{2}{|c|}{ Indikator Sikap } & \multicolumn{5}{|c|}{ Skor Perolehan } \\
\cline { 3 - 7 } & & $\mathbf{1}$ & $\mathbf{2}$ & $\mathbf{3}$ & $\mathbf{4}$ & $\mathbf{5}$ \\
\hline 1 & Kedisiplinan & & & & & \\
\hline 2 & Kejujuran & & & & & \\
\hline 3 & Kerjasama & & & & & \\
\hline 4 & $\begin{array}{l}\text { Mengakses dan } \\
\text { mengorganisasi informasi }\end{array}$ & & & & & \\
\hline 5 & Tanggung jawab & & & & & \\
\hline 6 & Memecahkan masalah & & & & & \\
\hline 7 & Kemandirian & & & & & \\
\hline 8 & Ketekunan & & & \\
\hline Ailtaitude (NAt) & & & & & & \\
\hline
\end{tabular}

Tabel 4. Rentang Predikat Penilaian Sikap

\begin{tabular}{|c|c|c|}
\hline Skor & Predikat & Status \\
\hline $000-69,00$ & D & Kurang Baik \\
\hline $70,0-79,0$ & C & Cukup \\
\hline $80,0-89,0$ & B & Baik \\
\hline $90,0-100$ & A & Amat Baik \\
\hline
\end{tabular}




\section{b. Pengumpulan Data Penilaian Proyek}

Data penilaian pekerjaan meliputi skor yang diperoleh dari tahap-tahap: perencanaan / persiapan, pengumpulan data, dan pengolahan data, pelaksanaan pekerjaan.

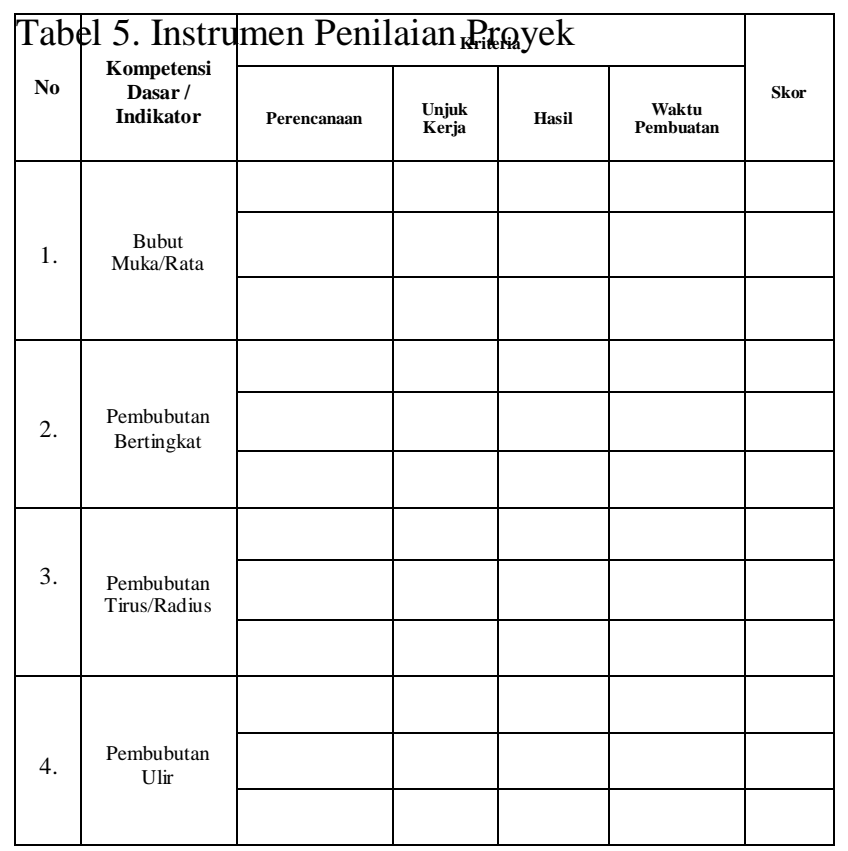

Sumber : Standar Penilaian Permendikbud No. 66

Tahun 2013

Data hasil penilaian proyek akan dianalisis dengan menggunakan rumus rata-rata dan persentase, di mana: $\bar{X}=\sum$ (Fraenkel, Jack R,. \&Wallen, Norman E, 2008: 192) $\bar{X}=$ rata-rata pencapaian hasil belajar siswa tiap indikator.

$X n=$ jumlah skor.

\section{F. Indikator Keberhasilan}

Hasil observasi menunjukkan bahwa nilai KKM untuk mata pelajaran MPMB adalah 80. Dari penjelasan tersebut, dapat disimpulkan bahwa indikator keberhasilan hasil belajar yang digunakan dalam penelitian ini yaitu:

1. Pada Siklus I, ketuntasan hasil belajar mencapai nilai KKM pada penilaian sikap dan praktek dengan presentase $60 \%$.

2. Pada Siklus II, ketuntasan hasil belajar mencapai nilai KKM pada penilaian sikap dan praktek dengan presentase $70 \%$.

3. Pada Siklus III, ketuntasan hasil belajar mencapai nilai KKM pada penilaian sikap dan praktek dengan presentase $80 \%$.

\section{Hasil Penelitian}

\section{A. Siklus I}

Penelitian ini bertujuan untuk meningkatkan hasil belajar siswa pada pembelajaran Melakukan Pekerjaan dengan Mesin Bubut di kelas XI Jurusan Teknik Mesin SMK Semen Padang dengan penerapan model pembelajaran berbasis proyek (project based learning) dengan mengintegrasikan basis GRASPS dalam pelaksanaannya. Hasil pengamatan siklus I dicatat dalam lembar instrumen penilaian sikap dan praktek yang telah dipersiapkan. Pengamatan pada siklus I diperoleh hasil pengolahan data instrumen penilaian sikap dan keterampilan sebagai gambaran dari hasil belajar siswa. Setelah dilaksanakan siklus I dalam pembelajaran menggunakan model pembelajaran berbasis proyek, nilai rata-rata siswa mencapai 81,61 dengan persentase ketuntasan klasikal sebesar 58\% pada penialaian hasil belajar praktek dan nilai rata-rata siswa mencapai 81,52 dengan presentase ketuntasan klasikal $67,74 \%$ pada penilaian sikap. Berdasarkan analisis data pada siklus I diperoleh perbandingan nilai hasil belajar awal siswa pada saat pre test adalah sebagai berikut:

\begin{tabular}{|c|c|c|c|c|}
\hline \multirow{2}{*}{$\begin{array}{c}\text { Tabel 6. Analisis Hasil } \\
\text { No }\end{array}$} & Prestasi & Belpiar SikluSeltah Siklus I \\
\cline { 4 - 5 } & & Test & Sikap & Keterampilan \\
\hline 1 & Nilai Tertinggi & 85 & 85 & 87,5 \\
\hline 2 & Nilai Terendah & 65 & 70 & 77,5 \\
\hline 3 & Rata-Rata & 78,7 & 81,52 & 81,61 \\
\hline 4 & $\begin{array}{c}\text { Prsentase } \\
\text { Ketuntasan }\end{array}$ & 51,61 & 67,74 & 58 \\
\hline
\end{tabular}

\section{Sumber : Analisis Data}

Analisis hasil belajar setelah Siklus I digambarkan dalam bentuk diagram batang sebagai berikut:

\section{Diagram Perbandingan Pre Tes dengan Siklus I}

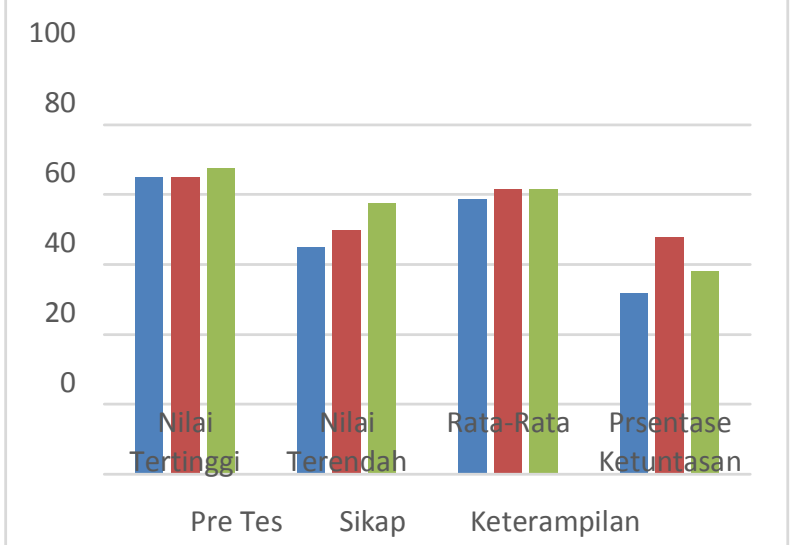

Gambar 2. Diagram Analisis Hasil Belajar Sebelum dan Setelah Siklus I. 


\section{B. Siklus II}

Hasil pengamatan siklus II dicatat dalam lembar instrumen penilaian sikap dan praktek yang telah dipersiapkan. Pengamatan pada siklus II diperoleh hasil penilaian dari pengolahan data instrumen penilaian sikap dan keterampilan sebagai gambaran dari hasil belajar siswa. Setelah siklus II dalam pembelajaran menggunakan model pembelajaran berbasis proyek, nilai rata-rata siswa mencapai 81,71 dengan persentase ketuntasan klasikal sebesar 77,42\% pada penialaian hasil belajar praktek dan nilai rata-rata siswa mencapai 82,58 dengan presentase ketuntasan klasikal $74,2 \%$ pada penilaian sikap. Berdasarkan analisis data pada siklus II diperoleh perbandingan nilai hasil belajar siswa setelah siklus I adalah sebagai berikut:

Tabel 7. Analisis Hasil Belajar Siklus II

\begin{tabular}{|c|c|c|c|c|c|}
\hline \multirow{2}{*}{ No } & \multirow{2}{*}{ Prestasi } & \multicolumn{2}{|c|}{ Setelah Siklus I } & \multicolumn{2}{|c|}{ Setelah Siklus II } \\
\cline { 3 - 6 } & Sikap & Keterampilan & Sikap & Keterampilan \\
\hline 1 & $\begin{array}{c}\text { Nilai } \\
\text { Tertinggi }\end{array}$ & 85 & 87,5 & 87,5 & 85 \\
\hline 2 & $\begin{array}{c}\text { Nilai } \\
\text { Terendah }\end{array}$ & 70 & 77,5 & 77,5 & 78,75 \\
\hline 3 & Rata-Rata & 81,52 & 81,61 & 82,58 & 81,71 \\
\hline 4 & $\begin{array}{c}\text { Prsentase } \\
\text { Ketuntasan }\end{array}$ & 67,74 & 58 & 72.3 & 77,42 \\
\hline
\end{tabular}

Sumber : Analisis Data

Analisis hasil belajar setelah Siklus II digambarkan dalam bentuk diagram batang sebagai berikut:

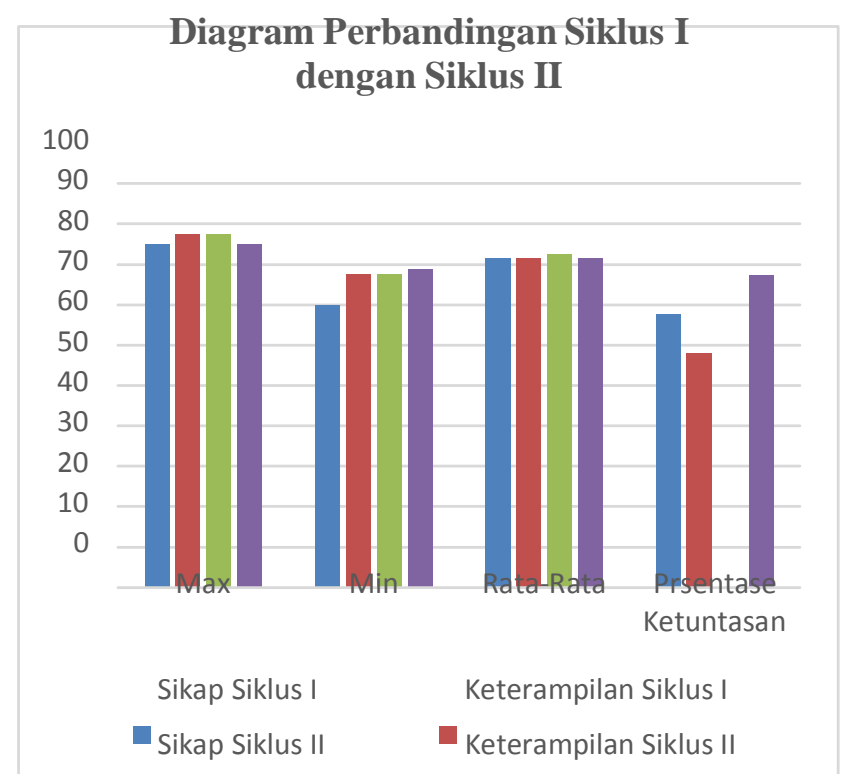

Gambar3. Diagram Analisis Hasil Belajar Sebelum dan Setelah Siklus II.

\section{Siklus III}

Hasil pengamatan siklus II dicatat dalam lembar instrumen penilaian sikap dan praktek yang telah dipersiapkan. Pengamatan pada siklus II diperoleh hasil penilaian dari pengolahan data instrumen penilaian sikap dan keterampilan sebagai gambaran dari hasil belajar siswa. Setelah siklus II dalam pembelajaran menggunakan model pembelajaran berbasis proyek, nilai rata-rata siswa mencapai 84,72 dengan persentase ketuntasan klasikal sebesar 93,54\% pada penialaian hasil belajar praktek dan nilai rata-rata siswa mencapai 85,48 dengan presentase ketuntasan klasikal $96,77 \%$ pada penilaian sikap. Berdasarkan analisis data pada siklus III diperoleh perbandingan nilai hasil belajar siswa setelah siklus II adalah sebagai berikut:

Tabel 8. Analisis Hasil Belajar Siklus III

\begin{tabular}{|c|c|c|c|c|c|}
\hline \multirow{2}{*}{ No } & \multirow{2}{*}{ Prestasi } & \multicolumn{2}{|c|}{ Setelah Siklus II } & \multicolumn{2}{c|}{ Setelah Siklus III } \\
\cline { 3 - 6 } & Sikap & Keterampilan & Sikap & Keterampilan \\
\hline 1 & $\begin{array}{c}\text { Nilai } \\
\text { Tertinggi }\end{array}$ & 87,5 & 85 & 90 & 90 \\
\hline 2 & $\begin{array}{c}\text { Nilai } \\
\text { Terendah }\end{array}$ & 77,5 & 78,75 & 77,5 & 78,75 \\
\hline 3 & $\begin{array}{c}\text { Rata-Rata } \\
4\end{array}$ & 82,58 & 81,71 & 85,48 & 84,72 \\
\hline Prsentase & 72.3 & 77,42 & 96,77 & 93,54 \\
\hline
\end{tabular}

Sumber : Analisis Data

Analisis hasil belajar setelah Siklus III digambarkan dalam bentuk diagram batang sebagai berikut:

\section{Diagram Perbandingan Siklus II dengan Siklus III}

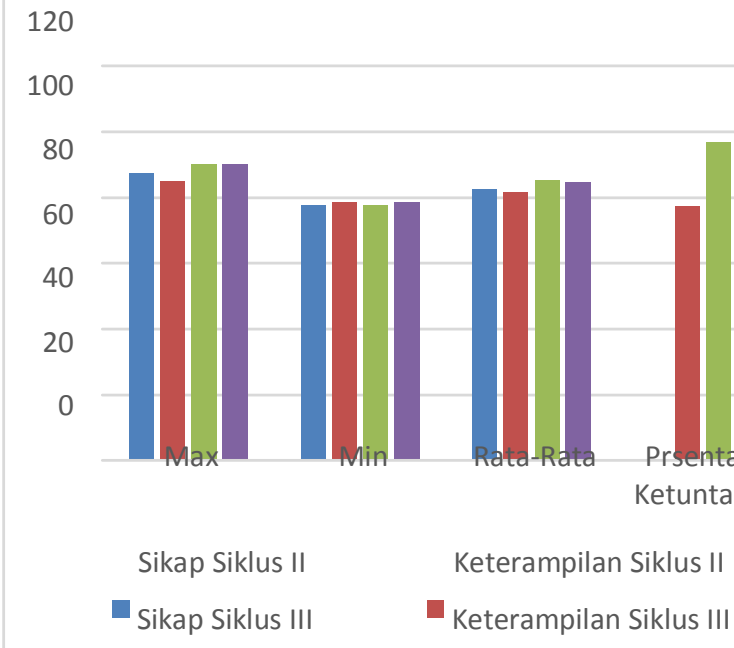

Gambar 4. Diagram Analisis Hasil Belajar Sebelum dan Setelah Siklus III. 


\section{Pembahasan}

Pembelajaran dengan menggunakan model project based learning atau model pembelajaran berbasis proyek memiliki banyak manfaat dan keuntungan. Proses pembelajaran Melakukan Pekerjaan dengan Mesin Bubut dengan menggunakan model project based learning selain menciptakan pembelajaran yang mendorong siswa untuk aktif dan kreatif memiliki tujuan agar siswa mempunyai kemandirian dalam menyelesaikan tugas yang dihadapi. Proses pembelajaran dengan menggunakan model project based learning dilihat dari segi pengamatan sikap siswa dalam proses pembelajaran di lapangan menunjukkan hasil baik. Berdasarkan analisis data hasil penelitian dapat dikatakan bahwa metode pembelajaran berbasis proyek atau $P J B L$ dapat meningkatkan hasil belajar siswa. Setelah dilakukan pembelajaran dengan menggunakan model pembelajaran berbasis proyek terlihat bahwa hasil belajar siswa mengalami peningkatan. Keaktifan siswa ditunjukkan dengan siswa mencoba mendesain sebuah proyek yang terkait dengan indeks pencapaian kompetensi pada silabus.

Sikap belajar terhadap pembelajaran juga mengalami peningkatan ke arah yang lebih baik. Siswa yang pada awalnya tidak disiplin dalam mengikuti pembelajaran, tidak berkomunikasi aktif, takut bertanya ataupun menjawab pertanyaan, serta tidak aktif dalam mencari sumber belajar dengan mandiri, menjadi antusias, dan tekun dalam proses pembelajaran. Secara umum peningkatan hasil belajar siswa pada tiap-tiap siklus dapat dilihat dari diagram berikut:

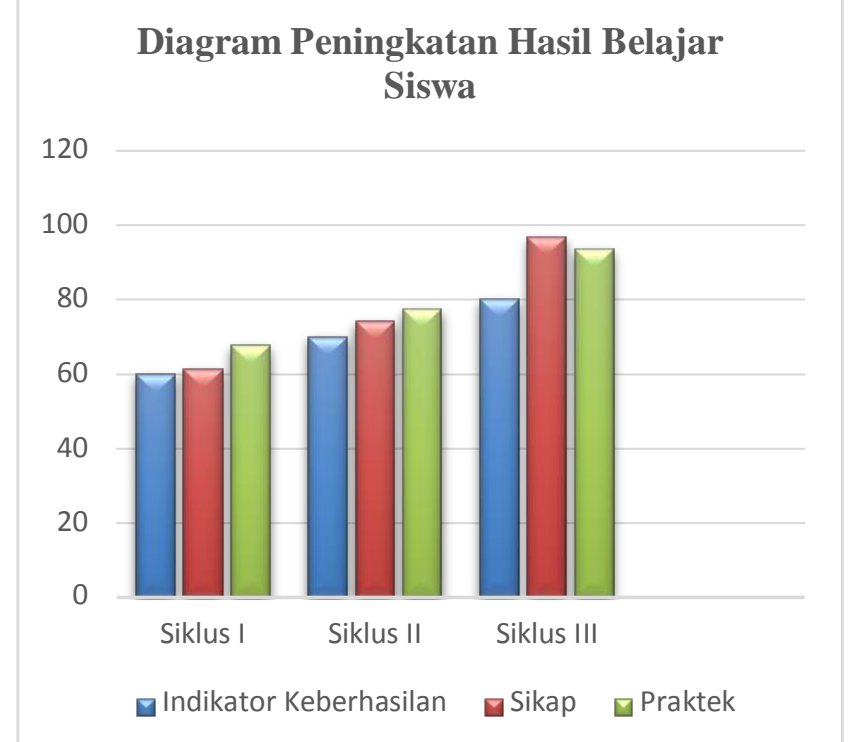

Gambar 5. Diagram Peningkatan Hasil Belajar Siswa.

\section{Siklus I}

Awal siklus pertama ini ketika model pembelajaran project based learning berbasis GRASPS dilakukan siswa secara menyeluruh belum mencapai ketuntasan belajar klasikal dan diantara siswa masih belum mampu untuk merancang sebuah proyek yang dapat dikerjakan dengan mesin bubut. Namun setelah diberikan pengertian dengan melihatkan contoh benda kerja yang sudah ada, maka siswa mulai memahami apa yang menjadi tujuan dari model pembelajaran berbasis proyek ini. Pada siklus I ini hasil belajar praktek siswa belum mencapai ketuntasan yaitu $60 \%$ dari jumlah siswa dan karena ada beberapa siswa yang tidak hadir.

\section{Siklus II}

Data yang diperoleh dari Siklus II menunjukkan ada usaha perbaikan dalam proses pembelajaran yang dilakukan oleh Peneliti dengan Kolaborator dalam upaya meningkatkan hasil belajar yang signifikan dari Siklus I ke Siklus II. Pada siklus II ini hasil belajar siswa sudah mencapai ketuntasan yaitu $70 \%$ dari jumlah siswa, namun ada beberapa siswa yang mengalami penurunan hasil belajar dibandingkan pada siklus pertama, oleh karena itu peneliti melanjutkan kesiklus selanjutnya.

\section{Siklus III}

Upaya penyempurnaan dan perbaikan terhadap Siklus II telah dilakukan, sehingga munculnya persaiangan yang positif antara kelompok siswa untuk unjuk kebolehan. Pada siklus III ini hasil belajar siswa telah mencapai indeks keberhasilan karena sebanyak 93,54\% siswa telah mencapai KKM, dari perencanaan indikator keberhasilan sebesar $80 \%$ pada Siklus III. Berdasarkan penelitian yang telah dilakukan, dapat disimpulkan bahwa penggunaan model pembelajaran project based learning berbasis GRASPS mampu meningkatkan hasil belajar siswa dikarenakan peranan guru hanya sebagai fasilitator maupun perantara untuk mendapatkan hasil yang optimal sesuai dengan daya imajinasi dan inovasi siswa, karena pada kelas XI kompetensi keterampilan abstraknya ada pada tahap K3-K5 yaitu tahap mencoba dan menyaji jadi dalam pelaksanaannya siswa diberikan kebebasan memilih gaya belajarnya sendiri. Hal ini tentunya menunjukkan bahwa selain meningkatkan hasil belajar, pembelajaran yang dilaksanakan juga berhasil meningkatkan kualitas proses pembelajaran.

\section{Penutup}

\section{A. Kesimpulan}

Hasil penelitian dapat disimpulkan sebagai berikut:

1. Pada siklus I, hasil belajar siswa mata diklat "Melakukan Pekerjaan dengan Mesin Bubut" dengan Penerapan PjBL berbasis GRASPS yang telah mencapai kriteria ketuntasan minimum 
(KKM) meningkat dari tes awal sebesar $51,61 \%$ (sebanyak 16 siswa) menjadi:

a. $67,74 \%$ (sebanyak 21 siswa) pada penilaian sikap.

b. $58 \%$ (sebanyak 18 siswa) pada penilaian praktek.

2. Pada siklus II, hasil belajar siswa mata diklat "Melakukan Pekerjaan dengan Mesin Bubut" dengan Penerapan PjBL berbasis GRASPS yang telah mencapai kriteria ketuntasan minimum (KKM) meningkat dari :

a. Penilaian Sikap dari $67,74 \%$ (sebanyak 21 siswa) menjadi $74,2 \%$ (sebanyak 23 siswa)

b. Penilaian Praktek dari 58\% (sebanyak 18 siswa) menjadi 77,42\% (sebanyak 24 siswa)

3. Pada siklus III, hasil belajar siswa mata diklat "Melakukan Pekerjaan dengan Mesin Bubut" dengan Penerapan PjBL berbasis GRASPS yang telah mencapai kriteria ketuntasan minimum (KKM) meningkat dari :

a. Penilaian Sikap dari $74,2 \%$ (sebanyak 23 siswa) menjadi 96,77\% (sebanyak 30 siswa)

b. Penilaian Praktek dari $77,42 \%$ (sebanyak 21 siswa) menjadi 93,54 (sebanyak 29 siswa)

Hasil penelitian tindakan kelas dengan 3 siklus dapat diketahui bahwa Penerapan Project Based Learning berbasis GRASPS pada mata diklat "Melakukan Pekerjaan dengan Mesin Bubut" dapat meningkatkan hasil belajar siswa.

\section{B. Saran}

Analisis hasil pengolahan data penelitian ini, peneliti dapat memberikan saran sebagai berikut:

1. Dengan penelitian tindakan kelas ini, diharapkan guru dapat mencoba menerapkan Project Based Learning berbasis GRASPS agar peningkatan hasil belajar siswa juga terjadi pada mata diklat lainnya, khususnya yang berhubungan dengan mata diklat produktif.

2. Bagi siswa diharapkan selalu meningkatkan keterlibatannya secara aktif untuk berkompetisi dalam proses pembelajaran. Siswa juga diharapkan terus meningkatkan kemandiriannya dalam melaksanakan pembelajaran. Peningkatan keterlibatan siswa dapat dilakukan dengan aktif berinteraksi dengan guru selama pembelajaran berlangsung, mengerjakan tugas, dan lain sebagainya.

3. Bagi peneliti selanjutnya diharapkan dapat menambah atau menambah jumlah sampel atau jumlah variabel yang diteliti untuk mendapatkan hasil penelitian yang lebih baik lagi.

\section{Daftar Pustaka}

Depdiknas. (2003). Undang-undang Republik Indonesia Nomor 20 Tahun 2003 Tentang Sistem Pendidikan Nasional. Jakarta: Depdiknas.

Depdiknas. (2009). Kurikulum Tingkat Satuan Pendidikan. Jakarta: Pusat Kurikulum, Balitbang Depdiknas.

Kusumah. (2010). Mengenal Penelitian Tindakan Kelas. Jakarta: PT. INDEKS.

Made Wena. (2009). Strategi pembelajaran inovatif kontemporer. Jakarta: Bumi Aksara.

Kemendikbud. (2013) Permendikbud No. 66 tentang Standar Penilaian Pendidikan. Jakarta: Kementrian Pendidikan dan Kebudayaan. 